\title{
Liquidity, Net Profit Margin, Growth of company terhadap Dividend Payout Ratio pada perusahaan Manufaktur
}

\author{
Riska Ariyani \\ Universitas Prima Indonesia \\ ariyaniriska172@gmail.com
}

\section{Febi Anatasya}

Universitas Prima Indonesia

febianatasya98@gmail.com

\section{Mayang Shinta Simanjuntak \\ Universitas Prima Indonesia \\ shinta.mms@gmail.com}

\begin{abstract}
Abstrak Devidend Payout Ratio merupakan persentase laba yang dibagikan dalam bentuk deviden tunai, yang berarti besar kecilnya devidend payout ratio ini akan mempengaruhi keputusan investasi pada pemegang saham dan disisi lain juga berpengaruh terhadap kondisi keuangan perusahaan. Penelitian ini bertujuan untuk menguji dan menganalisis Pengaruh Rasio Liquidity, Net Profit Margin dan Growth Of Company terhadap Dividend Payout Ratio pada Perusahaan Manufaktur yang Terdaftar di Bursa Efek Indonesia (BEI) tahun 20122016. Metode penelitian yang digunakan dalam penelitian ini adalah pendekatan kuantitatif. Jenis penelitian menggunakan penelitian kuantitatif dan sifat penelitian adalah penelitian kausal. Teknik analisis dalam penelitian ini adalah analisis regresi linear berganda. Berdasarkan hasil uji penelitian hipotesis secara simultan, Liquidity, net profit margin dan growth of company berpengaruh signifikan terhadap dividend payout ratio dengan hasil uji koefisien determinasi sebesar $32 \%$ dari varian variabel dividend payout ratio yang dapat dijelaskan oleh Liquidity, net profit margin dan growth of company dan $68 \%$ sisanya dijelaskan oleh variabel-variabel lain yang tidak diteliti dalam penelitian ini. Sedangkan berdasarkan hasil uji penelitian hipotesis secara parsial net profit margin dan growth of company tidak berpengaruh signifikan terhadap dividend payout ratio dan Liquidity berpengaruh positif dan signifikan terhadap dividend payout ratio.
\end{abstract}

Kata Kunci Likuiditas, marjin laba bersih, pertumbuhan perushaan.

\section{PENDAHULUAN}

\subsection{Latar Belakang}

Perusahaan yang terdaftar yang di Bura Efek Indonesia ( BEI ) semakin bertambah jumlahnya salah satunya adalah perusahaan manufaktur, hal ini menunjukkan semakin banyak pula transaksi saham yang terjadi di BEI dan biasanya investor pasti 
menginginkan adanya tingkat pengembalian yang lebih tinggi dibandingkan pengorbanan yang telah di keluarkan untuk mendapatkan invetasi tersebut. Oleh karena itu, deviden menjadi salah satu pertimbangan bagi investor untuk menanamkan modalnya di suatu perusahaan untuk mencari tingkat pengembalian investasi (Djoko dan Bambang, 2016).

Liquidity merupakan kemampuan perusahaan untuk membayar semua kewajiban jangka pendeknya secara tepat waktu. Liquidity mempunyai daya tarik saham kepada investor, jika perusahaan mampu melakukan pembayaran artinya perusahaan dalam keadaan likuid, tetapi bila perusahaan tidak mampu membayar dapat dikatakan perusahaan dalam keadaan inlikuid. Liquidity merupakan salah satu faktor yang diduga kuat mempengaruhi deviden. Perusahaan yang mampu memenuhi kewajiban jangka pendeknya berarti perusahaan itu juga mampu dalam membayar deviden(Kadek dan Ni Gusti, 2016).

Net Profit Margin menggambarkan seberapa besar persentase pendapatan bersih yang dapat dihasilkan oleh suatu perusahaan. Semakin besar rasio ini semakin baik karena dianggap kemampuan perusahaan dalam mendapatkan laba cukup tinggi (Nur dan Nova, 2016).

Laba sangat penting baik bagi perusahaan maupun bagi pihak investor, dimana perusahaan berkepentingan untuk menjaga kelangsungan hidup perusahaan. Perusahaan berkepentingan untuk mendanai prtumbuhan perusahaan, sementara disisi lain investor mengharapkan adanya pembagian keuntungan atas laba yang diperoleh deviden(Fenny dan Hening, 2013).

Berdasarkan uraian diatas peneliti akan memberikan gambaran tentang fenomenafenomena yang terjadi untuk menggambarkan "Pengaruh Liquidity, Net Profit Margin, Growth Of Company dan Dividend Payout Ratio pada Perusahaan Manufaktur yang terdaftar di Bursa Efek Indonesia tahun 2012-2016" dapat disajikan dalam bentuk tabel I.1 sebagai berikut:

Tabel 1.1 : Tabel Fenomena (Dalam Jutaan Rupiah)

\begin{tabular}{|c|c|c|c|c|c|c|c|}
\hline No & $\begin{array}{l}\text { Kode } \\
\text { Emiten }\end{array}$ & $\begin{array}{c}\text { Nama } \\
\text { Perusahaan }\end{array}$ & Tahun & $\begin{array}{l}\text { Utang } \\
\text { Lancar }\end{array}$ & Laba Bersih & $\begin{array}{c}\text { Total } \\
\text { Penjualaan }\end{array}$ & Dividen \\
\hline \multirow{5}{*}{1} & \multirow{5}{*}{ GGRM } & \multirow{5}{*}{$\begin{array}{l}\text { Gudang } \\
\text { Garam Tbk }\end{array}$} & 2012 & 13.802 .317 & 4.068 .711 & 49.028 .696 & 1.981 .627 \\
\hline & & & 2013 & 20.094 .580 & 4.383 .932 & 55.436 .954 & 1.571 .627 \\
\hline & & & 2014 & 23.783 .134 & 5.395 .293 & 65.185 .850 & 1.582 .869 \\
\hline & & & 2015 & 24.045 .086 & 6.452 .834 & 70.365 .573 & 1.567 .967 \\
\hline & & & 2016 & 21.638 .565 & 6.672 .682 & 76.274 .147 & 1.034 .368 \\
\hline \multirow{5}{*}{2} & \multirow{5}{*}{ AUTO } & \multirow{5}{*}{$\begin{array}{c}\text { PT. Astra } \\
\text { Otoparts Tbk }\end{array}$} & 2012 & 2.751 .766 & 1.135 .914 & 8.277 .485 & 314.226 \\
\hline & & & 2013 & 2.661 .312 & 1.058 .015 & 10.701 .988 & 544.987 \\
\hline & & & 2014 & 3.857 .809 & 956.409 & 12.255 .427 & 439.536 \\
\hline & & & 2015 & 3.625 .907 & 322.701 & 11.723 .787 & 299.471 \\
\hline & & & 2016 & 3.258 .146 & 483.421 & 12.806 .867 & 128.924 \\
\hline \multirow{4}{*}{3} & \multirow{4}{*}{ HMSP } & \multirow{4}{*}{$\begin{array}{l}\text { PT. Hanjaya } \\
\text { Manda } \\
\text { Sampoerna } \\
\text { Tbk }\end{array}$} & 2012 & 11.897 .977 & 9.945 .296 & 66.626 .123 & 6.793 .650 \\
\hline & & & 2013 & 12.123 .790 & 10.818 .486 & 75.025 .207 & 9.945 .027 \\
\hline & & & 2014 & 13.600 .230 & 10.181 .083 & 80.690 .139 & 10.650 .690 \\
\hline & & & 2015 & 4.538 .674 & 10.363 .308 & 89.069 .306 & 12.250 .485 \\
\hline
\end{tabular}


Berdasarkan Tabel I.1 dapat dilihat yang terjadi pada PT. Gudang Garam Tbk pada tahun 2012-2016, Laba Bersih pada tahun 2012-2013 mengalami peningkatan sebesar7,74\%. Dividen pada tahun 2012-2013 mengalami penurunan sebesar 20,69\% .Pada PT. Astra Otoparts Tbk pada tahun 2012-2016, Hutang Lancar pada tahun 20132014 mengalami peningkatan sebesar 44.95\%. Dividen pada tahun 2013-2014 mengalami penurunan sebesar 19,34\%. Pada PT. Hanjaya Manda Sampoerna Tbk pada tahun 2012-2016, Total Penjualan pada tahun 2014-2015 mengalami peningkatan sebesar 10,38\%. Dividend pada tahun 2014-2015 mengalami peningkatan sebesar $15,02 \%$.

\subsection{Tujuan Penelitian}

Berdasarkan latar belakang permasalahan yang telah diuraikan di atas, maka tujuan yang didapat dalam penelitian ini adalah sebagai berikut:

1. Untuk menguji dan menganalisis pengaruh Liquiditysecara parsial terhadap Dividend Payout Ratio pada perusahaan manufaktur yang terdaftar di Bursa Efek Indonesia tahun 2012-2016.

2. Untuk menguji dan menganalisis pengaruh Net Profit Margin (NPM)secara parsial terhadap Dividend Payout Ratio pada perusahaan manufaktur yang terdaftar di Bursa Efek Indonesia tahun 2012-2016.

3. Untuk menguji dan menganalisis Growth Of Companysecara parsial terhadap Dividend PayoutRatio pada perusahaan manufaktur yang terdaftar di Bursa Efek Indonesia tahun 2012-2016.

4. Untuk menguji dan menganalisis pengaruh Liquidity, Net Profit Margin(NPM), dan Growth Of Companysecara simultan terhadap Dividend Payout Ratio pada perusahaan manufaktur yang terdaftar di Bursa Efek Indonesia tahun 2012-2016.

\section{LANDASAN TEORI}

\subsection{Liquidity}

Menurut Sunyoto (2013:86), arti penting rasio likuiditas merupakan suatu tingkat kemampuan yang bersifat relative, karena itu jika perusahaan berada dalam keadaan kurang likuid, ada kemungkinan perusahaan tidak bisa memanfaatkan kesempatan potongan (pembelian,tunai) yang ditawarkan oleh para leveransirnyaakibatnya perusahaan terpaksa beroperasi pada tingkat biaya yang tinggi, sehingga mengurangi kesempatan untuk meraih laba yang lebih besar. Rasio liquidity yang digunakan dalam penelitian ini adalah Current Ratio.Sebagai bagian dari rasio likuiditas, indikator ini mengukur kemampuan perusahaan dalam menyelesaikan kewajiban jangka pendeknya tepat waktu atau sebelum jatuh tempo (Munawarah dan Hayati, 2019: 6).Rumus untuk mencari liquidity dapat digunakan sebagai berikut :

\subsection{Net Profit Margin}

$$
\text { Rasio Lancar }=\frac{\text { Aktiva Lancar }}{\text { Utang Lancar }}
$$


Menurut Hery (2017:198), margin laba bersih merupakan rasio yang digunakan untuk mengukur besarnya persentase laba bersih atas penjualan bersih. Rasio ini dihitung dengan membagi laba bersih terhadap penjualan bersih.

\subsection{Growth Of Company}

$$
\text { Marjin laba bersih }=\frac{\text { Laba Bersih }}{\text { Penjualan Bersih }}
$$

Menurut Fahmi (2014:82), rasio pertumbuhan yaitu rasio yang mengukur seberapa besar kemampuan perusahaan dalam mempertahankan posisinya di dalam industri dan dalam perkembangan ekonomi secara umum. Rasio pertumbuhan ini yang umum dilihat dari berbagai segi yaitu dari segi sales (penjualan), earning after tax (EAT), laba perlembar saham, dividen perlembar saham, dan harga pasar perlembar saham.

$$
\text { Kenaikan Penjualan }=\frac{\text { Penjualan Tahun Ini }- \text { Penjualan Tahun Lalu }}{\text { Penjualan Tahun Lalu }}
$$

\subsection{Dividend Payout Ratio}

Menurut Sudana (2015:26), rasio ini mengukur berapa besar bagian laba bersih setelah pajak yang dibayarkan sebagai dividen kepada pemegang saham,semakin besar rasio ini berarti semakin sedikit bagian laba yang ditahan untuk membelanjai investasi yang dilakukan perusahaan.

$$
(D P R)=\frac{\text { Dividend }}{\text { Earning after taxes }}
$$

\subsection{Penelitian Terdahulu}

Nur dan Nova(2016),meneliti tentang Pengaruh Kebijakan Hutang Earning Per Share, Net Profit Margin, Profitabilitas Terhadap Dividend Payout Ratio Pada Perusahaan Yang Terdaftar Di LQ45. Hasil Penelitian menyatakan bahwa Profitabilitas secara parsial berpengaruh signifikan terhadap Dividend Payout Ratio sedangkan Kebijakan Hutang Earning Per Share, Net Profit Margin, Profitabilitas secara bersama-sama berpengaruh signifikan terhadap Dividend Payout Ratio.

Christy (2015), meneliti tentang Pengaruh Rasio Profitabilitas, Likuiditas Dan Leverage Terhadap Dividend Payout Ratio Pada Perusahaan Farmasi Yang Terdaftar Di Bursa Efek Indonesia. Hasil Penelitian menyatakan bahwa secara parsial Rasio Profitabilitas berpengaruh signifikan terhadap Dividend Payout Ratio. Likuiditas dan Leverage tidak berpengaruh signifikan terhadap Dividend Payout Ratio sedangkan secara simultan Pengaruh Rasio Profitabilitas, Likuiditas dan Leverage Terhadap Dividend Payout Ratio tidak berpengaruh signifikan.

Fenny dan Hening (2013),meneliti tentang Cash Ratio, ROA, Dan Growth Of CompanyTerhadapDividend Payout Ratio. Hasil Penelitian menyatakan bahwa Cash Ratio secara parsial tidak berpengaruh signifikan terhadap Dividend Payout Ratio.Return On Aset dan Pertumbuhan Perusahaan secara parsial berpengaruh berpengaruh signifikan terhadap Dividend Payout Ratio sedangkan secara simultan Cash Ratio Return On Aset dan Pertumbuhan Perusahaan secara bersama-sama berpengaruh signifikan terhadap Dividend Payout Ratio. 


\subsection{Kerangka Konseptual}

Kerangka konseptual dapat digambarkan di bawah ini sebagai berikut:

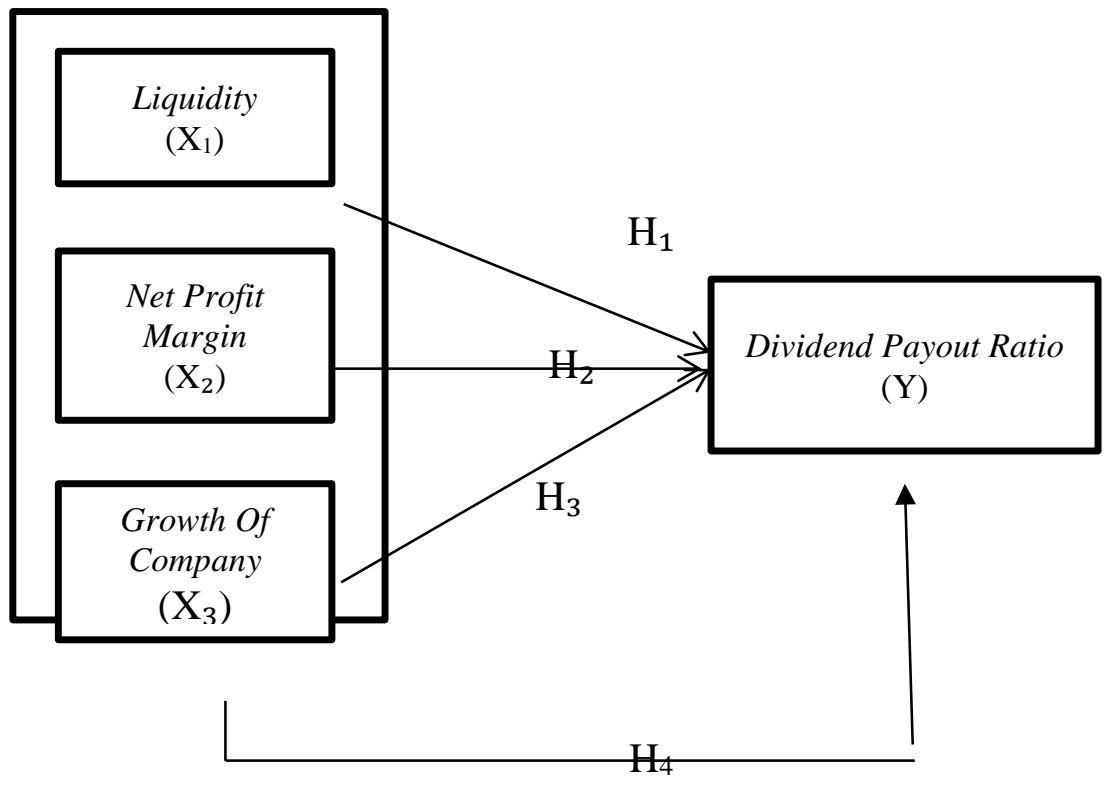

\section{Gambar II.1 Kerangka Konseptual}

\section{METODOLOGI PENELITIAN}

Menurut Sugiyono (2016), pendekatan penelitian dalam peneliti ini adalah penelitian kuantitatif. Jenis penelitian ini digunakan menggunakan deskriptif.Sifat penelitian dalam penelitian ini adalah kausal.Penelitian ini dilakukan pada perusahaan manufaktur yang terdaftar di Bursa Efek Indonesia tahun 2012-2016. Data yang digunakan dalam penelitian ini adalah laporan keuangan perusahaan manufaktur yang terdaftar di Bursa Efek Indonesia pada tahun 2012-2016.Populasi dalam penelitian ini adalah laporan keuangan perusahaan Manufaktur yang terdaftar di Bursa Efek Indonesia periode 2012-2016 yang berjumlah 144 perusahaan.Data dalam penelitian ini adalah perusahaan manufaktur dan data runtun waktunya adalah tahun 2012, 2013, 2014, 2015, 2016.Teknik pengambilan sampel mengunakan teknik purposive sampling. Data yang digunakan dalam penelitian ini adalah data sekunder, yaitu berupa laporan keuangan perusahaan manufaktur yang terdaftar di Bursa Efek Indonesia pada tahun 2012-2016. Sumber data adalah situs resmi Bursa Efek Indonesia (BEI) di www.idx.co.id

\section{HASIL PENELITIAN}

\subsection{Uji Normalitas}

Uji normalitas bertujuan untuk menguji apakah model regresi, variabel pengganggu atau residual memiliki distribusi normal. Uji normalitas yang digunakan dalam penelitian ini yaitu dengan melihat analisis grafik probability plots. 


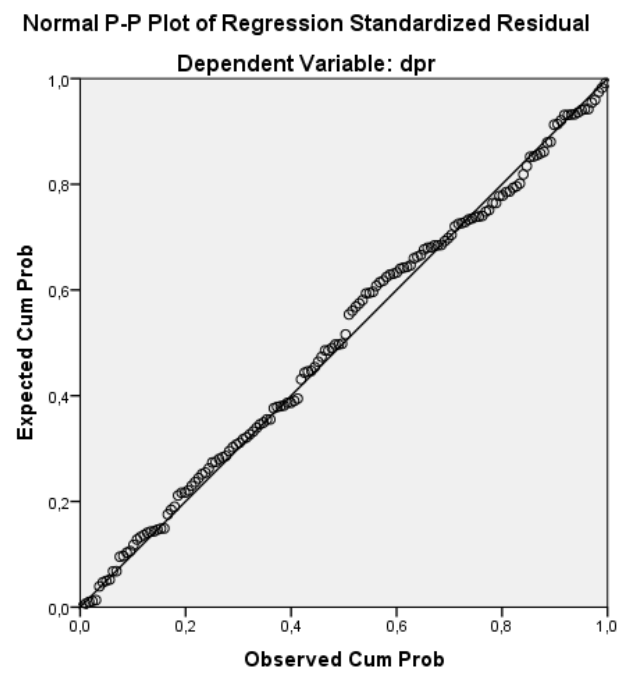

\section{Gambar IV.1 Hasil Uji Normalitas - Probability Plots}

Dari grafik normal probability plot (Gambar IV.1) terlihat titik-titik menyebar disekitar garis diagonal, dan mengikuti arah diagonal. Hal ini menunjukkan distribusi normal, maka model regresi memenuhi asumsi normalitas.

\subsection{Uji Multikolineritas}

Uji multikolonieritas dapat dilakukan dengan melihat nilai tolerance dan nilai VIF dengan kriteria nilai tolerance $>0,10$ dan nilai VIF $\leq 10$. Berikut adalah hasil uji multikolonieritas :

\section{Tabel 4.1 Hasil Uji Multikolineritas}

Coefficients $^{\text {a }}$

\begin{tabular}{|c|c|c|c|c|c|c|c|}
\hline \multirow[b]{2}{*}{ Model } & \multicolumn{2}{|c|}{$\begin{array}{c}\text { Unstandardized } \\
\text { Coefficients }\end{array}$} & \multirow{2}{*}{$\begin{array}{c}\text { Standardized } \\
\text { Coefficients } \\
\text { Beta }\end{array}$} & \multirow[b]{2}{*}{$\mathrm{T}$} & \multirow[b]{2}{*}{ Sig. } & \multicolumn{2}{|c|}{$\begin{array}{c}\text { Collinearity } \\
\text { Statistics }\end{array}$} \\
\hline & B & $\begin{array}{l}\text { Std. } \\
\text { Error }\end{array}$ & & & & $\begin{array}{l}\text { Toleran } \\
\text { ce }\end{array}$ & VIF \\
\hline $1 \quad$ (Constant) & & & & - & & & \\
\hline &,- 936 & ,285 & & $\begin{array}{r}3,28 \\
5\end{array}$ & ,001 & & \\
\hline liquidity & ,099 &, 042 & , 189 & 2,36 & ,019 & ,990 & 1,010 \\
\hline npm & ,132 & ,095 &, 110 & 1,38 & , 169 & ,993 & 1,007 \\
\hline growth &,- 005 & ,067 &,- 006 & $\begin{array}{r}- \\
070\end{array}$ & ,944 & ,996 & 1,004 \\
\hline
\end{tabular}

a. Dependent Variable: $\ln \_d p r$

Berdasarkan hasil uji multikolonieritas pada (Tabel IV.1) dapat dilihat bahwa VIF terendah adalah variabel Growth Of Company yaitu sebesar 1,004, sedangkan nilai VIF 
terbesar adalah Liquidity yaitu sebesar 1,010, terlihat bahwa semua variabel independen memiliki nilai tolerance $>0,010$ dan nilai VIF $<10$. Hal ini menunjukkan bahwa model ini tidak terjadi Multikolineritas.

\subsection{Uji Autokorelasi}

Uji autokorelasi bertujuan untuk menguji apakah dalam model regresi linear ada korelasi antara kesalahan pengganggu periode $t$ dengan kesalahan pengganggu periode $\mathrm{t}-$ 1 (sebelumnya).Uji autokolerasi dalam penelitian ini dilakukan dengan menggunakan Durbin-Watson. Berikut adalah hasil Durbin-Watson adalah:

Tabel IV.2 Hasil Uji Autokorelasi Model Summary ${ }^{\mathrm{b}}$

\begin{tabular}{|l|c|r|r|r|r|}
\hline Model & $\mathrm{R}$ & R Square & $\begin{array}{c}\text { Adjusted R } \\
\text { Square }\end{array}$ & $\begin{array}{c}\text { Std. Error of } \\
\text { the Estimate }\end{array}$ & $\begin{array}{c}\text { Durbin- } \\
\text { Watson }\end{array}$ \\
\hline 1 &, $226^{\mathrm{a}}$ &, 051 &, 032 &, 76323 & 1,942 \\
\hline
\end{tabular}

a. Predictors: (Constant), growth, npm, liquidity

b. Dependent Variable: dpr

Dari (tabel IV . 2) di atas menunjukkan bahwa diperoleh nilai devidend payout ratio Durbin Watson sebesar 1,942. Pada penelitian ini, k adalah jumlah banyaknya variabel bebas maka $\mathrm{k}=3 \mathrm{n}$ adalah banyaknya observasi maka $\mathrm{n}=154$ nilai $\mathrm{dl}=1,693 \mathrm{dan} \mathrm{du}=$ 1,774 dan $4-\mathrm{du}=2,226$. Dengan melihat kriteria pada pedoman Durbin-Watson maka nilai $\mathrm{du}<\mathrm{dw}<4$-du atau 1,774 < 1,942 <2,226 maka hasil uji autokorelasi menunjukkan bahwa pada model tersebut tidak terjadi autokorelasi positif maupun negatif dengan keputusan tidak ditolak.

\subsection{Uji Heteroskedasitas}

Uji heteroskedastisitas bertujuan untuk menguji apakah dalam regresi terjadi ketidaksamaan variance dari residual satu pengamatan ke pengamatan lain. Uji heterokedastisitas dalam penelitian ini dilakukan dengan cara melihat grafik scatterplot dan uji glejser. 


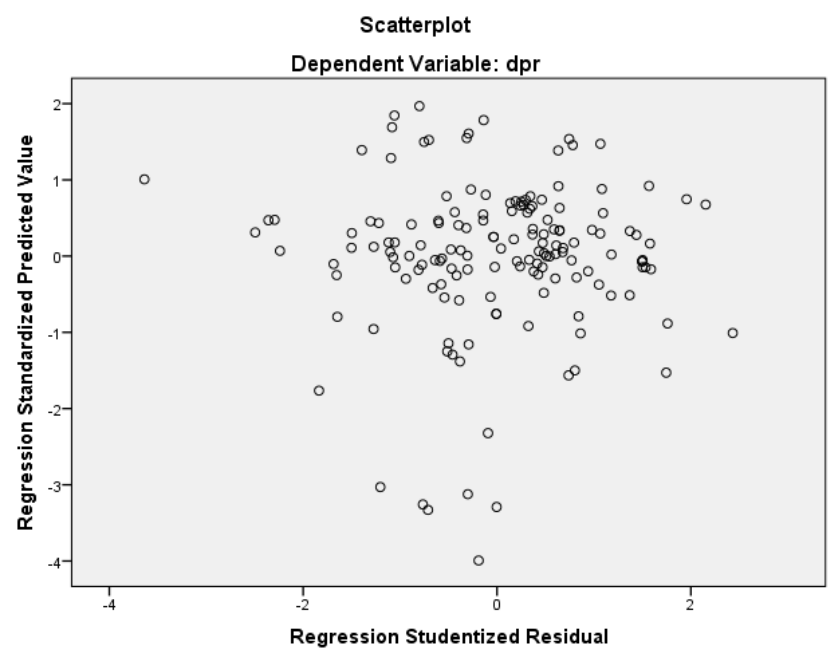

Gambar 4.2 Grafik Scatterplot

Dari grafik Scatterplot (gambar IV.2) dapatdilihat bahwa tidak adanya pola yang jelas, serta titik-titik menyebar di atas dan di bawah angka 0 pada sumbu Y yang artinya tidak terjadi heteroskedasitas pada model regresi

Tabel IV.3 Hasil Ujil Glejser

Coefficients $^{\mathbf{a}}$

\begin{tabular}{|c|c|c|c|c|c|c|c|}
\hline \multirow[b]{2}{*}{ Model } & \multicolumn{2}{|c|}{$\begin{array}{c}\text { Unstandardized } \\
\text { Coefficients }\end{array}$} & \multirow{2}{*}{$\begin{array}{c}\begin{array}{c}\text { Standardiz } \\
\text { ed } \\
\text { Coefficien } \\
\text { ts }\end{array} \\
\text { Beta } \\
\end{array}$} & & \multirow[b]{2}{*}{ Sig. } & \multicolumn{2}{|c|}{$\begin{array}{l}\text { Collinearity } \\
\text { Statistics }\end{array}$} \\
\hline & B & $\begin{array}{l}\text { Std. } \\
\text { Error }\end{array}$ & & & & $\begin{array}{c}\text { Toleran } \\
\text { ce }\end{array}$ & VIF \\
\hline $\begin{array}{ll}1 & \text { (Constant } \\
& \text { ) }\end{array}$ &, 543 & , 176 & & 3,085 & ,002 & & \\
\hline $\begin{array}{l}\text { ln_liquidi } \\
\text { ty }\end{array}$ & ,029 & ,026 & ,094 & 1,141 & ,256 & ,955 & 1,047 \\
\hline ln_npm &, 014 & ,057 &, 020 &, 250 & ,803 & ,981 & 1,020 \\
\hline $\begin{array}{l}\text { ln_growt } \\
\mathrm{h}\end{array}$ &, 013 &, 040 &, 026 & ,322 & ,748 & ,996 & 1,004 \\
\hline ln_dpr &,- 089 & ,049 &,- 152 & $-1,828$ & 070 & 949 & 1,054 \\
\hline
\end{tabular}

a. Dependent Variable: absut

Berdasarkan hasil uji Glejser pada (tabel IV.3), nilai signifikan semua variabel independen lebih besar dari 0,05 yang artinya model regresi tidak mengalami masalah heterokedastisitas yang juga didukung dengan hasil grafik scatterplot. 


\section{IV.4 Analisis Regresi Linear Berganda}

Tabel 4.4 Hasil Persamaan Regresi Linear Berganda Coefficients $^{\mathbf{a}}$

\begin{tabular}{|c|c|c|c|c|c|c|c|}
\hline \multirow[b]{2}{*}{ Model } & \multicolumn{2}{|c|}{$\begin{array}{c}\text { Unstandardized } \\
\text { Coefficients }\end{array}$} & \multirow{2}{*}{$\begin{array}{c}\begin{array}{c}\text { Standardiz } \\
\text { ed } \\
\text { Coefficien } \\
\text { ts }\end{array} \\
\\
\text { Beta }\end{array}$} & \multirow[b]{2}{*}{$\mathrm{T}$} & \multirow[b]{2}{*}{ Sig. } & \multicolumn{2}{|c|}{$\begin{array}{c}\text { Collinearity } \\
\text { Statistics }\end{array}$} \\
\hline & B & $\begin{array}{l}\text { Std. } \\
\text { Error }\end{array}$ & & & & $\begin{array}{c}\text { Toleran } \\
\text { ce }\end{array}$ & VIF \\
\hline $1 \quad$ (Constant &,- 936 & ,285 & & $-3,285$ & ,001 & & \\
\hline liquidity & ,099 & ,042 &, 189 & 2,363 & ,019 & ,990 & 1,010 \\
\hline Npm &, 132 & ,095 &, 110 & 1,382 & , 169 & 993 & 1,007 \\
\hline Growth &,- 005 & ,067 &,- 006 &,- 070 & 944 & 996 & 1,004 \\
\hline
\end{tabular}

a. Dependent Variable: dpr

Persamaan regresi yang terbentuk berdasarkan hasil olah data adalah sebagai berikut : $Y=-0,9360,009 X_{1} 0,132 X_{2}-0,005 X_{3}+e$

Keterangan :

$\mathrm{Y}=$ Devidend Payout Ratio

$\mathrm{X}_{1}=$ Liquidity

$\mathrm{X}_{2}=$ Net Profit Margin

$\mathrm{X}_{3}=$ Growth Of Company

Hasil interpretasi dari persamaan regresi tersebut adalah sebagai berikut :

1. Nilai konstanta (a) sebesar $-0,936$ artinya jika variabel liquidity, net profit margin ,growth of company bernilai nol atau konstan maka nilai devidend payout ratioadalah sebesar $-0,936$.

2. Nilai koefisien regresi liquidity adalah 0,099 menunjukkan bahwa setiap kenaikan liquidity satu satuan maka devidend payout ratio mengalami kenaikan sebesar 0,099.

3. Nilai koefisien regresi net profit margin adalah 0,132 menunjukkan bahwa setiap kenaikan net profit margin satusatuan maka devidend payout ratiomengalami kenaikan sebesar 0,132 .

4. Nilai koefisien regresi growth of company adalah -0,005 menunjukkan bahwa setiap kenaikan growth of company satu satuan maka devidend payout ratiomengalami penurunan sebesar $-0,005$.

\section{IV.5 Koefisien Determinasi}


Tabel 4.5 Koefisien Determinasi Hipotesis Model Summary ${ }^{b}$

\begin{tabular}{|c|c|c|c|c|c|}
\hline Model & $\mathrm{R}$ & $\mathrm{R}$ Square & $\begin{array}{c}\text { Adjusted R } \\
\text { Square }\end{array}$ & $\begin{array}{c}\text { Std. Error of } \\
\text { the Estimate }\end{array}$ & $\begin{array}{c}\text { Durbin- } \\
\text { Watson }\end{array}$ \\
\hline 1 &, $226^{\mathrm{a}}$ &, 051 &, 032 &, 76323 & 1,942 \\
\hline
\end{tabular}

a. Predictors: (Constant), ln_growth, ln_npm, ln_liquidity

Berdasarkan (tabel IV. 5), nilai Adjusted $\mathrm{R}^{2}$ adalah 0,032. Dengan demikian dapat disimpulkan bahwa kemampuan variabel independen (liquidity, net profit margin, dan growt of company) dalam menerangkan variasi variabel dependen (devidend payout ratio) adalah sebesar $32 \%$, sedangkan sisanya sebesar $68 \%$ dijelaskan oleh variabel-variabel lain di luar model penelitian ini.

\section{IV.6 Pengujian Secara Simultan (Uji-F)}

Tabel 4.6 Hasil Pengujian Secara Simultan (Uji F) ANOVA ${ }^{\mathrm{a}}$

\begin{tabular}{|c|c|c|c|c|c|c|}
\hline & Model & $\begin{array}{l}\text { Sum of } \\
\text { Squares }\end{array}$ & $\mathrm{df}$ & Mean Square & $\mathrm{F}$ & Sig. \\
\hline 1 & Regression & 4,692 & 3 & 1,564 & 2,685 &, $049^{b}$ \\
\hline & Residual & 87,377 & 150 & ,583 & & \\
\hline & Total & 92,070 & 153 & & & \\
\hline
\end{tabular}

a. Dependent Variable: dpr

b. Predictors: (Constant), growth, npm, liquidity

Berdasarkan hasil uji $\mathrm{F}$ pada (tabel 6), nilai $\mathrm{F}_{\text {hitung adalah 2,685 dengan tingkat }}$ signifikan 0,049 $<0,05$ sedangkan $F_{\text {tabel }}$ sebesar 2,66 (df1 = k-1 = 4-1 = 3: df $2=n-k=$ $154-4=150)$. Hal ini menunjukkan bahwa nilai $F_{h i t u n g}>F_{\text {tabel }}$ yaitu 2,685 $>2,66$ dan nilai signifikan $<0,05$ yang berarti bahwa $\mathrm{H}_{\mathrm{O}}$ diterima yang artinya bahwa variabel liquidity, net profit margin dan growth of company secara simultan berpengaruh signifikan terhadap dividend payout ratio pada perusahaan manufaktur yang terdaftar di Bursa Efek Indonesia tahun 2012-2016.

\subsection{Pengujian Secara Parsial (Uji T)}

\section{Tabel 4.7. Hasil Uji T \\ Coefficients $^{\mathrm{a}}$}

\begin{tabular}{|c|c|c|c|c|c|c|c|c|}
\hline & \multirow[b]{2}{*}{ Model } & \multicolumn{2}{|c|}{$\begin{array}{c}\text { Unstandardized } \\
\text { Coefficients }\end{array}$} & \multirow{2}{*}{\begin{tabular}{|c|}
$\begin{array}{l}\text { Standardized } \\
\text { Coefficients }\end{array}$ \\
Beta \\
\end{tabular}} & \multirow[b]{2}{*}{$\mathrm{T}$} & \multirow[b]{2}{*}{ Sig. } & \multicolumn{2}{|c|}{$\begin{array}{c}\text { Collinearity } \\
\text { Statistics }\end{array}$} \\
\hline & & $\mathrm{B}$ & Std. Error & & & & Tolerance & VIF \\
\hline 1 & (Constant) &,- 936 &, 285 & & $-3,285$ &, 001 & & \\
\hline & liquidity & ,099 & ,042, & , 189 & 2,363 & ,01s & 990, & 1,010 \\
\hline & npm & , 132 & 095 &, 110 & 1,382 &, 16 & 993 & 1,007 \\
\hline & growth &,- 005 & ,067 &,- 006 &,- 070 & ,944 & ,996 & 1,004 \\
\hline
\end{tabular}

a. Dependent Variable: dpr 
Berdasarkan tabel 4.7 liquidity memiliki nilai t-hitung lebih besar daripada t-tabel dan nilai signifikan dibawah 0,05 liquidity berpengaruh signifikan terhadap devidend payout ratio, sedangkan net profit margin dan growth of company memiliki nilai t-hitung lebih kecil daripada t-tabel dan nilai signifikan diatas 0,05 sehingga net profit margin dan growth of company tidak berpengaruh signifikan terhadap devidend payout ratio

\section{Pengaruh Liquidity, Net Profit Margin dan Growth Of Company Terhadap Dividend Payout Ratio}

Liquidity, net profit margin dan growth of company secara simultan berpengaruh signifikan terhadap dividend payout ratio. Untuk menguji hipotesis tersebut digunakan uji F, di peroleh F hitung sebesar 2,685 dengan tingkat signifikan 0,049=0,05.

\section{Pengaruh Liquidity Terhadap Dividend Payout Ratio}

Liquidity berpengaruh positif dan signifikan terhadap dividend payout ratio. Dari hasil analisis regresi diperoleh $t$ hitung sebesar 2,363 dengan $t$ tabel sebesar 1,9759 karen $t$ hitung > t tabel sehingga dapat diambil kesimpulan bahwa Likuidias secara parsial berpengaruh terhadap dividend payout ratio. Likuiditas dapat dibayarkan dalam bentuk dividen tunai atau dividen saham. Perusahaan hanya mampu membayar dividen tunai jika tingkat likuiditas (cash ratio) yang dimiliki perusahaan mencukupi. Semakin tinggi tingkat likuiditas perusahaan, semakin besar dividen tunai yang mampu membayar perusahaan kepada pemegang saham, dan sebaliknya. Hal ini mengindikasikan bahwa likuiditas merupakan salah satu faktor yang mempengaruhi dividend payout ratio. Hasil penelitian ini tidak didukung oleh penelitian yang dilakukan oleh (Christy,2015),yang menyatakan bahwa liquidity tidak berpengaruh terhadap naik turunnya dividend payout ratio.

\section{Pengaruh Net Profit MarginTerhadap Dividend Payout Ratio}

Net profit margin secara parsial tidak berpengaruh signifikan terhadap dividend payout ratio. Dari hasil analisis regresi diperoleh t hitung sebesar 1,382 dengan t tabel sebesar 1,9759 karen $t$ hitung $<\mathrm{t}$ tabel sehingga dapat diambil kesimpulan bahwa Net profit margin secara parsial tidak berpengaruh terhadap dividend payout ratio. Jika laba perusahaan cenderung stabil, perusahaan dapat membagikan dividen yang relatif besar tanpa takut harus menurunkan dividen jika laba tiba-tiba merosot. konsekuensinya: laba ditahan menjadi besar dan dividen menjadi mengecil. Hasil penelitian ini didukung oleh penelitian yang dilakukan oleh (Nur dan Nova, 2016), yang menyatakan bahwa net profit margin yang dimiliki perusahaan belum bisa digunakan untuk membayar dividend payout ratio.

\section{Pengaruh Growth Of Company Terhadap Dividend Payout Ratio}

Growth of company secara parsial tidak berpengaruh secara signifikan terhadap dividend payout ratio. Dari hasil analisis regresi diperoleh t hitung sebesar -070 dengan $t$ tabel sebesar 1,9759 karen $\mathrm{t}$ hitung $<\mathrm{t}$ tabel sehingga dapat diambil kesimpulan bahwa secara parsial Growth of company tidak berpengaruh terhadap dividend payout ratio. semakin cepat tingkat pertumbuhan perusahaan semakin besar kebutuhannya untuk membiayain pengembangan harta perusahaan tersebut, dan semakin banyak dana yang dibutuhkan di kemudian hari, semakin banyak pula keuntungan yang harus ditahan dan 
bukan untuk dibayarkan kepada pemegang saham dalam bentuk dividen (dividen relatif kecil). Hal ini mengindikasikan bahwa pertumbuhan perusahaan bukan merupakan salah satu faktor yang mempengaruhi dividend payout ratio. Hasil penelitian ini tidak didukung oleh penelitian yang dilakukan oleh (Fenny dan Hening, 2013),yang menyatakan bahwa Growth of company berpengaruh secara signifikan terhadap dividend payout ratio.

\section{KESIMPULAN}

Berdasarkan hasil penelitian, peneliti dapat menarik kesimpulan sebagai berikut :

1. Liquidity secara parsial berpengaruh positif dan signifikan terhadap dividend payout ratio pada perusahaan manufaktur yang terdaftar di Bursa Efek Indonesia tahun 2012-2016. Sedangkan Net profit margin dan Growth of company secara parsial tidak berpengaruh secara signifikan terhadap dividend payout ratio pada perusahaan manufaktur yang terdaftar di Bursa Efek Indonesia tahun 2012-2016.

2. Liquidity, net profit margin dan growth of company secara simultan secara simultan berpengaruh signifikan terhadap dividend payout ratio pada perusahaan manufaktur yang terdaftar di Bursa Efek Indonesia tahun 2012-2016.

\section{DAFTAR PUSTAKA}

Djoko, A. P., \& Bambang, S. (2016). Pengaruh Profitabilitas, Free Cash Flow, Investment Opportunity Set Terhadap Dividend Payout Ratio. Jurnal Ilmu dan Riset Akuntansi : Volume 5, Nomor 1.

Fahmi, Irham. 2014. "Manajemen Keuangan Teori dan Soal Jawab". Cetakkan Ketiga:Alfabeta,Bandung.

Fenny, P.,\& Hening, W. O. (2013).Pengaruh Cash Ratio, ROA, Dan Growth Of Company terhadap Dividend Payout Ratio.Jurnal Ilmu \& Riset Manajemen Vol.2 No. 4.

Harahap, Sofyan Syafri. 2015. “Analisis Kritis atas Laporan Keuangan”. Penerbit: PT.Rajagrafindo Persada, Jakarta.

Hery. 2017. “Analisis Laporan Keuangan Integrated and Comprehensive Edition”. Cetakkan kedua, Penerbit : PT.Grasindo, Jakarta.

Kadek, D. M. Y., \& Ni Gusti, P. W. (2016). Pengaruh Net Profit Margin, Current Ratio, Dan Debt To Equity Ratio Pada Devidend Payout Ratio. E- Jurnal Akuntansi Universitas Udayana Vol.16.2.

Munawarah, M., \& Hayati, K. (2019). Accuracy Of Springate, Zmijewsky And Grover As Logistic Models In Finding Financial Difficulty of Financing Companies. ACCRUALS, 3(1), 1-12

Nur, A. Y., \&Nova, F. (2016). Pengaruh Kebijakan Hutang, Earning Per Share, Net Profit Margin Dan Profitabilitas Terhadap Dividend Payout Ratio Pada Perusahaan Yang Terdaftar Di LQ45 Periode 2010-2014. Jurnal Akuntansi dan Keuangan ISSN: 2301-4717 Vol 4, Nomor 1, p, 129-146.

Christy, R. Dkk. (2015).Pengaruh Rasio Profitabilitas, Likuiditas, dan Leverage Terhadap Dividend Payout Ratio Pada Perusahaan Farmasi Yang Terdaftar Di Bursa Efek Indonesia. Jurnal Berkala Ilmiah Efisiensi Vol 15 No.05.

Sudana, I Made. 2015. “Teori\&Praktik Manajemen Keuagan Perusahaan".Edisi kedua, Erlangga. 
Sugiyono. 2016. “Metode Penelitian Kuantitatif, kualitatif, dan $R \& D ”$. Penerbit: Erlangga, Jakarta.

Sunyoto, Danang. 2013. “Analisis Laporan Keuangan Untuk Bisnis Teori Dan Kasus”. Cetakan Pertama: CAPS(Centere of Academic Publishing Service),Jakarta. www.idx.co.id 